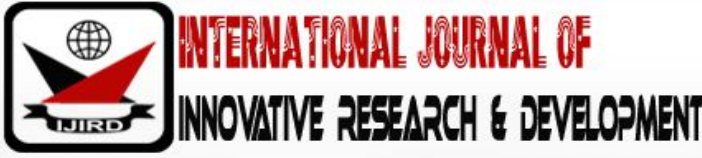

ISSN 2278 - 0211 (Online)

\section{The Agenda Setting Concept: Exploring Press Reports about the Military and Boko Haram in Nigeria}

Ben-Collins Emeka Ndinojuo
Research Fellow, Department of Linguistics and Communication Studies,
University of Port Harcourt, Nigeria
W. C. Ihejirika
Professor, Department of Linguistics and Communication Studies,
University of Port Harcourt, Nigeria
Dr. G. B. Okon
Senior Lecturer, Department of Mass Communication,
Rivers State University of Science and Technology, Nigeria

\begin{abstract}
:
The agenda setting theory of the press has been dealt with on numerous occasions in scholarship about communication studies and press theories. In examining press reports about military operations against the Boko Haram group underpinned by the agenda setting theory of the press, this paper explores the realities from press expositions about occurrences in North East Nigeria. An independent press reduces the likelihood of bias in reporting while the chance of accuracy and objectivity increases. To increase the chances of this happening, the press needs more access to the conflict zone. Between the actors in any conflict, there is a symbiotic relationship, for the media to act as validators of actions ascribed to them, either as liberators/ terrorists on one hand or freedom fighters/ oppressor on the other hand. The military are viewed as the liberators while the Boko Haram insurgents are the terrorists while on the other paradigm, Boko Haram view themselves as freedom fighters and the Nigerian government/military as the oppressors. The agenda that redeems the media is that of accuracy with little room for bias when reporting news stories. Ensuring that as many sources from all the sides are involved before publishing is essential, otherwise, it borders on bias or even the extreme falsehood that today can be aided by technology that spreads within seconds globally.
\end{abstract}

Keywords: Agenda setting, military, Boko Haram, Nigeria, newspapers

\section{Introduction}

The Nigerian military has been battling the Boko Haram insurgent group since 2009 when they turned violent beyond the control of police. The protracted nature of the conflict has defied predictions of resolutions where the public assumed these may be another form of militancy already experienced by Nigeria in the South. This paper explores how the press has set the agenda in news reports about military operations against the group. Some scholars have faulted the role the press have played in reporting the conflict as a whole (Shehu, 2015; Hamid \& Baba, 2014; Ayoola \& Olaosun, 2014; Olagunju \& Ajadi, 2014; Lawrence, 2011). Some reports also argue that newspaper reports have demoralized troops fighting the insurgents in the past (Audu, 2013; Haruna, 2017; Erunke, 2017). Overall, the overarching question is, has this been in consonance with the agenda setting theory of the press?

The agenda setting theory of the press was first introduced by McCombs and Shaw (1972) in their groundbreaking study on the 1968 presidential election where Democratic Party incumbent President Lyndon B. Johnson was ousted by the Republican Party challenger Richard Nixon. They surveyed 100 residents of Chapel Hill, North Carolina on what they thought were the most important issues of the election and how that compared to what was reported by the local and national media as the most important issues.

The frequency of coverage newspapers give to an issue increases public interest and awareness for the topic under consideration and this could also affect the level of social importance that is attributed to it. McCombs and Shaw (1972) called this the "agenda setting" effect of news, and this has been tested by researchers over the years. Their primary precept was that there is a relationship between the amount of interest a certain issue receives in news media and the extent to which the 
public considers this issue to be of exceptional importance. Succinctly put, what is considered important by the news media is also considered important by the public (Jönsson, 2011), this can be gauged by discussions in the public domain at gatherings or on internet discussion forums.

\subsection{The Military and Press in Nigeria}

The media reporting of wars has increased since the mid-nineteenth century, the first documented effort of reporting the outcome of a battle was credited to the Battle of Marathon in $490 \mathrm{BC}$ when a Greek soldier Pheidippides ran all the way from the battle front to Athens (roughly 42 kilometers in three hours) to report the Greek victory. His valiant effort gave birth to the Marathon race as we know it today (Humayun \& Ramani, 2015; Singh, 2006). Professional war correspondents were first deployed in the coverage of the Mexican War (1846-48) where the newspaper correspondent used horseback messengers, steamboats, telegraph lines in order to publish before the official release by the military (Potter, 2008). Overtime, media capabilities have greatly improved with satellite transmissions from mobile phones and other devices capable of relaying messages from any front in seconds.

The military or more generally the Armed Forces of a country are the government-sponsored organization responsible for the defense of the country from both internal and external aggressors. They are made up of different specialized fighting units depending on location. The Army is generally the ground soldiers, the Navy is trained to battle in water (seas and oceans) and the Airforce fights from planes in the air. Humayun and Ramani (2015) point out that military operations; because of their offensive nature are often times misunderstood by a greater population of the general public; therefore, they are planned and executed in secrecy. The media on the other hand has its cardinal objective as providing information and exposing secrets to the public. Singh (2006) continues that the public has a right to know what the military does. This objectively means that the relationship between the press and the military will not be getting better anytime soon as they both try to get better at their jobs, one being more secretive, the other attempting to expose more secrets. The internet has greatly aided the press with organisations such as Wikileaks leaking classified government secrets globally, and Sahara Reporters in Nigeria publishing stories that most mainstream newspapers naturally refrain from publishing.

In democracy and as practiced in Nigeria, the military is supposed to be accountable to the public as it is perceived as an extension of the executive branch, while the public uses the legislature to hold the various units of the executive accountable. The media role as the fourth estate of the realm is to serve as the enabler by making available the essential information that the people need to make decisions through their elected representatives in the National Assembly comprising the Senate and the House of Representatives in Nigeria. Media competition also drives the press into an information overdrive where journalists are always on the lookout for the next "exclusive" or "breaking news" that will keep the media organisation in the spotlight driving ads and international recognition for the journalist(s) and organisation they represent.

The military and the press in Nigeria today have been more cordial compared to the periods before the return of democracy in 1999. This was because the military have been in charge of governing Nigeria for longer stretches since independence in 1960 and as an organisation, the military abhors dissent - which is one of the cornerstones of journalism presenting counter arguments that may not be pleasing to who is being opposed. Nzimiro (1988) notes that the relationship between the press and military differed from regime to regime, not so much was documented during the early Aguiyi-Ironsi, Gowon, and Murtala military regimes, but with the coming of Buhari government in 1983, press relations differed with arrest of journalists and closure of media houses (Vourlias, 2015; Osu \& Pate, 2011; Adeyemi, 1998). The Babangida regime of 1985 recorded arrests, closures and assassination of journalists (Seng \& Hunt, 1986) and this continued during the Abacha regime from 1993 (Udomisor \& Anayo, 2013; Nwokegi, 2009). Okoye (2003) highlighted some reasons for the acrimonious relationship between the military and the press and they include:

- Mutual distrust - the press has often times been accused by the military of being irresponsible and unpatriotic while carrying out their duties. The press on the other hand accuses the military of deviating from promises made after taking over power especially with regards to when to conduct elections and hand over power to civilians. This mutual distrust has been carried over from military dictatorship years into civilian administrations with the military regarding the press as unpatriotic by reporting on military casualties while the military is accused of high handedness and lack of regard for the rule of law.

- Too much secrecy - the press views the military as a $\mathrm{n}$ organization that conducts most of its business in secret divulging little or no information to the public and in the process endangering the public safety. In the war against Boko Haram, the military will inform the public that normalcy has returned to an area that was recently attacked in order to show the public it is in charge while in reality if they were really in charge, the attack would have been repelled and never have happened in the first place. Thus, the military will promote public safety in the open but in secret; it is a question of every person for himself.

- Corruption of military officials - many government officials have used security as a means of corruptly enriching themselves at the expense of the lives of the people they swore an oath to protect. The press because of its information provision function has been used to expose such corrupt practices (Aluko, 2017; Osas, 2014) and in the process have come under attack from the military and other security operatives (Ibekwe, 2017; Ogundipe, 2017).

- Refusal of military to take the media into confidence on matters of national interest - in the ongoing war against Boko Haram, the media involvement has been somewhat from afar and sometimes not parallel with government positions 
with the military not taking the media in confidence on security issues (Shettima, 2015). The military has been forced to change press releases on the account of inconsistencies with later reports. The Chibok girls kidnapping controversy in 2014 was one where the government denied its earlier position that no girls were kidnapped (Ibeh \& Audu, 2014; Audu, 2014; Ibeh, 2014); and the ambush of soldiers and oil exploration team of Nigeria National Petroleum Corporation, NNPC and University of Maiduguri staff with the military claiming to have rescued all those involved losing 9 soldiers, however, later reports suggested a higher figure forcing the military to retract and apologize for its earlier account of events (Idowu, 2017).

In both cases, taking the media into confidence would have been better for the military as they can collaborate to come up with better approaches to present the tragedies to the public. The military and the press should understand that both stand for the same ideal, which is promoting a peaceful and stable society where all are equal, as such closer cooperation between them should be encouraged. Shettima (2015) conclusively stated government must regard the media as partners in progress by taking them in confidence on security matters. Olayinka and Onwuka (2016) also advise the media to be discreet about reporting on military strategies and operations if they are to gain the trust of the government and military.

Involving members of the media during military operations means that such operations will be guided by procedures that all participants must strictly adhere to. This was also the challenge faced by the United States of America where conflicts arose about how to objectively report military operations. The US Military decided that it was proper for the media to inform the public and the congress about their military operations for accountability and transparency. The Sidle Commission report (1984) was set up to work out a framework to guide the media-military relationship in combat situations. The commission was set up to look at the modalities of getting the media more involved in reporting on the United States military operations without compromising the lives of military officers and operations.

The Amnesty International report in 2018 was widely reported across news media where the Nigeria military was accused of starving and raping women in IDP camps (Amnesty International, 2018; Premium Times, 2018). The military considered such reports malicious and damaging (Dauda, 2018; Defence Headquarters, 2018), and for them, regardless of whether the allegations were true or false. To them, the objectives of such reports are to damage the reputation of the military as an institution before its international partners. Such accusations have the potential to affect the fight against the insurgents negatively as international partners may decline to sell arms to Nigeria because of such accusations. The key to resolution of such allegations is the unrestricted access to the media to the IDP camps to be able to report about the conditions, as the allegations centered on scarcity of food for those in the IDP camps, thus the soldiers were now accused of using food to lure the helpless women into sex while some are raped.

\subsection{Agenda Setting Theory}

The agenda-setting ideology of the press can be traced to the postulate of Lippmann (1922), where he claimed that topics to be considered news worthy and of public interest were offered to the public by the media. However, agenda-setting as a theory was developed from the empirical research that was conducted in the early 1970s by McCombs and Shaw (1972), their focus was on the 1968 American presidential election. They investigated publications by some media organisations in Chapel Hill, North Carolina in the days leading up to the elections. They classified the topics presented by the media into 5 main categories while also conducting a survey among undecided voters (Pavelka, 2014).

In doing this, they gathered information about the main campaign issues for the media and the public. They discovered that there was a strong correlation between what the media and the public considered as main campaign issues. Specifically, the five most pressing campaign topics corresponded with the five most pressing campaign topics of the undecided voters that took part in the study. Based on the research findings, they proposed a hypothesis advocating that the media advances the public topics or agendas which are accepted by the public knowingly or unknowingly. According to the agenda-setting theory, the media thus have the power to influence their audience's thinking and to offer the audience the most important topics (Pavelka, 2014).

The general theme behind the agenda setting theory of the press is the perceived media influence on the public where news items made prominent influences the prominence of items in the public discourse, and if public talks about such issues long enough, they could result to a call for action that may be positive or negative depending on how the media has framed such issues. Carroll and McCombs (2003) distinctly describe this principle as "the prominence of elements in the news influences the prominence of those elements among the public" (p.36). They further recognize two levels of media agenda setting where the first level is concerned with the salience of objects (public issues, public figures, or companies) and the second level is concerned with the salience of the characteristics of those objects.

The press presents an agenda of those topics they consider salient hoping that it will resonate with the public and lead to an action that calls for a review of how the government or its agencies have tackled the issues raised for the benefit of the society and promotion of peaceful coexistence. The focus of this paper is extrapolations from newspaper reports of military operations against Boko Haram in the North East of Nigeria examining the coverage of the conflict.

Agenda setting studies have focused on varying topics, but some of the most frequently researched issues are how agenda setting is used in politics especially in political disputes and campaigns as was the origin of the agenda setting theory by McCombs and Shaw in 1972. McCombs (1997) portrayed agenda setting as the "transmission of salience, not the determination of opinions pro and con about a particular issue" (p. 433). He went on to say that news media do not purposely 
set the agenda in their releases; rather, "the topics that are chosen to be the main focus in a news story can affect the opinions of the audience" (p. 433). In addition, how such stories are repeated can have a lasting effect in the minds of the audience because of repeated exposure.

McCombs (1997) continues that the impact that news articles have on the population is limited, because they may help the public arrive at a consensus but they alone do not decide what the consensus will be. The press because of their roles and functions to the society may be in a better position to articulate and make simpler government policy decisions to enable understanding of complex issues by the audience which may include doctors, teachers, artisans, bankers, etc. who in our case may have little or no understanding of long term government security policies and positions that may have far reaching ramifications on the society.

With regards to reporting about military operations against the insurgent group in Nigeria that has left thousands dead and millions more displaced, the press can support government efforts against the group not just by publishing press release as sent out by the military. But by also praising military gallantry in tackling the insurgents especially those injured or killed, with the commitment that their efforts will not be in vain. They can highlight benefits accruing to the family of soldiers who are injured or killed in confrontations with the group to motivate those currently posted in the North East of Nigeria. Such reports are capable of attracting local and international support instead of always painting a rosy picture of imminent defeat of the Boko Haram group yet reports of keep surfacing of daring attacks against military formations and communities in the North East.

The press reported with much fanfare the fall of the Boko Haram supposed headquarter in Sambisa forest with military approval (Nnanna, 2016), but reporting on issues that have affected troop morale has been characterized by the military hierarchy as anti-government (360News, 2016; The Punch, 2016). In the real sense, such reports of military challenges should serve as a wakeup call to the military top brass who have been alleged to divert funds meant for prosecution of the war against the group leading to nonpayment of allowances of soldiers involved the war (Baker, 2015; Dan Fulani, 2014) and also shortage of food and water for soldiers where YouTube videos supposedly uploaded by aggrieved Nigerian soldiers showed them complaining of going days without food and water (Nwabughiogu, 2016; The Punch, 2016).

The press sets the agenda in this instance by torch lighting issues capable of derailing the war in order to make them issues of public discourse and also for the relevant government agencies to rise up to their duties and put in place corrective measures that will halt practices where allowances already released by government are held up by bureaucratic processes or corrupt officials and basic amenities such as food and water required for any human being to be able to function are always in place.

McCombs (1997) mentions the importance of proactive agenda-setting. He states that, "these journalists believe that it is the duty and responsibility of the news media to ensure through proactive reporting when necessary that the key issues, situations, and opportunities do come to community attention" (p. 439). McCombs further clarifies by stating that journalists by their profession are privileged and that the core assumption of public journalism and proactive agenda-setting is that this privilege should be actively used to benefit the public by highlighting salient issues bringing them to the public domain and government attention.

This could be one of the ways the Boko Haram group escaped government radar because the press failed to adequately project the poverty and suffering of the North East population thus opening the door for religious extremists to take advantage of the situation by promising to change the plight of the suffering and poverty stricken population. This narration is captured by the popular aphorism of the German philosopher Karl Marx in 1843 - "religion is the opium of the people" (McKinnon, 2005, p.15).

Other philosophers have previously captured the effects of religion on the suffering population. Novalis in 1798 described this when he stated that "their so-called religion works simply in opiate- stimulating; numbing; quelling pain by means of weakness" (O'Brien, 1995, p.154). Heinrich Heine in 1840 using the same analogy in his treatise on Ludwig Borne captures it thus "welcome be a religion that pours into the bitter chalice of the suffering human species some sweet, soporific drops of love, hope and faith" (Heine, 2006). This research does not in any way downplay the importance and significance of religion in maintaining societal decorum especially in a multiethnic and multi-religious country like Nigeria, rather, it highlights the vacuum that religious extremists fill when government fails to address economic ills bedeviling the people aided by media negligence of such ills.

Religious extremists will have a fertile ground to recruit and indoctrinate new members swelling their ranks, increasing their popularity and making their defeat more difficult if not impossible if they decide to go up in arms against the government of the day. This situation is applicable to the Boko Haram insurgency where the Nigerian military has claimed to defeat the group severally, but yet, the group keeps resurfacing, pillaging villages, attacking military bases and ambushing military convoys. A narrative that fits their resurgence is the ability to recruit new and willing members who have been radicalized citing government neglect and non-attention given to their plight by media outfits.

In retrospect, the media has not seen their conditions fit enough to set as an agenda of discourse in their reportage and publications until it becomes the crises it has evolved into. Agenda setting helps in shaping how the public views an issue. Shaw (1979) supports this in his claim that agenda setting of the press has a direct effect on the public's perception. Although the public are free to interpret a news story based on their understanding, on the other hand, how the media reports a story can influence public opinion about the issue being discussed regardless of whether the public are aware of this media 
influence or not. He explains further that cumulation is a media trait used in reinforcing media agenda. He defines cumulation as the "persistent usage in the press of a topic, trend, or theme, because of the repeated publicity given them by the media, the favoured topics tends to dominate the attention of the audience" (p.102).

It remains to be seen how the media in Nigeria set the agenda and applied cumulation in their coverage of stories about the poverty, unemployment, low literacy rates that was prevalent in the North East (compared to other regions especially those in the South) prior to the escalation of the Boko Haram insurgency. More studies can be carried out to find out the presence and application of cumulation in Nigeria newspapers in their reporting of the economic realities in the North East prior to the emergence of Boko Haram and also possibly to other parts of Nigeria affected by poverty.

In relation to this paper's point of argument, newspapers can use agenda setting to ensure that military operations against Boko Haram are adequately covered to keep Nigerians abreast of trend and direction of military campaigns. Freyenberger (2013) sums up the relevance of media agenda setting and cumulation as it relates to specific issues with the statement that "the cognition of a topic is more prominent in an individual's mind when that topic is repeated over a long period of time in the media" (p.19). Although, cumulation does not depict reality as the Nigerian press has kowtowed the government line of the defeat of the Boko Haram insurgents, this has not deterred from the reality that the group still has the capability of staging mass kidnappings of school girls in 2018, to reprise their globally-condemned mass kidnapping of school girls in Chibok, Borno state, North East Nigeria.

Freyenberger (2013) continues that sensationalism is another aspect of media agenda setting to draw public attention to an individual, and in our situation causes that have great ramification for the socioeconomic sustenance of any society. The Nigerian press and the media generally can be said to easily sensationalize stories about conflicts, bomb blasts, high profile kidnappings and other unusual occurrences. However, there is scarcely little evidence to support the view that the same sensationalism is applied in highlighting social problems faced by residents of the North East and other developmentally challenged regions like the Niger Delta especially communities that have been negatively affected by activities of oil exploration companies.

McQuail (2010) is of the view that sensationalism is used by media organisations as a mechanism to gain public attention and prompt emotional sentiments to elicit sympathy from the audiences. Sensationalism generates a certain degree of interest in a news story by using language or graphics that are electrifying, spine-tingling, outrageous and breathtaking. The agenda-setting theory of the press is an important parameter that provides information that enables researchers to better understand how an issue of public concern is presented by journalists to the society. In as much as the media audiences have the ability to come to conclusions regarding how they view newspaper reports on the topic of discourse, newspaper organisation can influence thoughts and inadvertently impose agendas on their audience.

Pavelka (2014) informs that later studies showed that the agenda setting process is more complicated than was originally thought, and frequency of coverage alone was not sufficient to influence public opinion. In addition to frequency, the manner in which issues are addressed, framed, and primed as well as the sociopolitical and cultural context play a significant role in influencing public attitude towards a topic. On this premise, we shall discuss the framing theory further in the next section.

\subsection{Media and Terrorism}

Terrorism has been a global security challenge for many countries in the world today with millions of deaths attributed to terror acts in the last decade (Global Terrorism Index, 2016). It was a tactic adopted by some nationalists in the Americas and popularized by religious fundamentalists mainly in the Middle East to press home their demands against their adversaries. Today, only a handful of countries have escaped terror attacks which has seen relatively peaceful countries like Nigeria, Ivory Coast, Tanzania (Ekwueme \& Obayi, 2012), experiencing terror attacks while cosmopolitan cities like London, Paris, Berlin experience terror attacks intermittently (Bervanakis, 2017; Foster, 2017; Phipps \& Weaver, 2016). In all these, the major objective of the terrorists is the media coverage that comes with such attacks and the expected fear that the magnitude of the attack hopes to strike in the minds of the civilian population, government officials and security organisations.

In Nigeria, the main terrorist organisation and focal to this paper is the Jama'atu Ahlis Sunna Lidda'awati wal-Jihad people committed to the propagation of the Prophet's teachings and Jihad otherwise known as Boko Haram. They have waged a brutal and deadly war since 2009 against the Nigerian government and residents of North East Nigeria resulting in the deaths of thousands and displacement of millions of people not only in Nigeria, but also in Cameroun, Chad and Niger Republic. Journalists have also been targeted with the bombing of The Moment, ThisDay, and The Daily Sun newspapers in April 2012 (Reporters Without Border, 2013)

The primary function of the media is to provide information to the society. This function makes them central to the enlightenment and promotion of agendas either individual, group, societal or government agenda. Terrorists use the media to promote their agendas which for Boko Haram is that Western education is evil as such all Muslims must refrain from Western education while non-Muslims must convert to Islam or face their wrath. Journalists they deem not reporting favourably for the group or distorting their messages or suspected of being government spies are threatened, attacked, and in worse case scenarios killed to serve as deterrent to other journalists reporting about the group.

The relationship between journalists and insurgents has some symbiotic tendencies where they both benefit from each other (Ngige, Badekale \& HammanJoda, 2016; Hoffman, 2006). To lend credence to this, Popoola (2012) opined that 
insurgency and conflict is the bread and butter of journalism. Conflicts generally serve as news material to be reported by journalists. The reading audiences are interested in getting detailed accounts of any such terrorist activities as they occur, while the media organisation increases circulation and profit due to the increased attention and ad revenue.

The terrorist organisation as well gets the much needed media coverage they crave especially from the mainstream media organisations which legitimizes their actions (knowingly or unknowingly) and in some way ensures they will be at the negotiating table at some point in the future. The various militant groups in the Niger Delta used this tactic to make headline in order to negotiate beneficial amnesty terms and lucrative security contracts for their leaders (Ibekwe, 2015; Ujah, 2012). The Boko Haram group so far has resisted government invitations to the negotiation table although they have been rumoured to have received payments for the release of hostages (Akinkuotu, Umukoro, Akinloye \& Aluko, 2017; Ukpong, 2017b; Ogundipe, 2016)

Peresin (2007) does not agree that the relationship between the media and terrorist groups is symbiotic. She is of the view that the primary aim of terrorists is to intimidate and manipulate journalists in other to achieve their own end. They achieve this by sending messages depicting the violence and mayhem they leave behind and in the process gain mass publicity for their bizarre acts. To her, the terrorists' benefits more from the relationship with the media because it is already the job of journalists to report news worthy events. Not covering terror stories could be tantamount to dereliction of duties, which may give room to quacks taking over the job of reporting where the mainstream news organisations have abandoned reporting issues of public interest and curiosity. Rather (2012) furthermore avers that by reporting about the frightening terrorist activities, the media becomes complicit as this helps to bring the much sought after attention which was the original goal for groups involved in terror acts.

The Boko Haram terrorists in Nigeria according to Ngige, Badekale and HammanJoda (2016) benefit from press coverage where the objectives and tactics of the group are exposed to both national and international coverage. Walsh (2010) however, sees the media coverage from a professional standpoint and argues that reporting insurgency is a public policy issue that deserves media coverage because it is a matter of grave public importance with wider ramifications for residents and businesses as well as government at all levels in the affected region.

The global village of information network that has been enhanced by the internet and its myriads of applications have also helped terrorist groups to reach out directly to the audience bypassing the media that used to serve as conduit for getting messages in the public domain. Information dissemination by groups such as Boko Haram has become easier with internet applications such as Facebook, Twitter and most especially YouTube which they have used to broadcast terror acts such as public floggings, beheadings, hangings, and shooting to death of people they consider enemies including journalists accused of being spies or reporting pro-government news (CNN, 2015; The Young Turks, 2015; Carvell, 2014).

For the journalists reporting about insurgencies and conflicts, it is important to try to get as much versions of the events to give the reporter a better chance of writing a balanced and objective reporting. Journalists in most situations in carrying out their surveillance and information function with regard to security stories about conflict may report mostly about government positions when reporting conflicts in order to be seen as patriotic or pro-government and not security risks. This is especially true for journalists in developing countries as they are at greater risk of being arrested, jailed or even killed in the line of duty.

For the sake of accuracy and objectivity in reporting news, journalists should try to hear from all the actors involved in the conflict because this gives everyone a sense of belonging and have a way of helping during negotiations for ceasefire or cessation of hostilities. The journalist's report should be more focused on de-escalation of hostilities rather than reports leading to more violence. Getting as many accounts of the story also helps the journalist when framing stories as they will have a better idea of what to include, exclude and which detail to give more focus and those to play down.

\subsection{Media-Source Dynamics in the Agenda Setting Paradigm}

Examining journalists and their sources can be traced back to questions about influence, bias and the agenda being advocated by media players. The nature of the sources is thereby crucial in understanding the agenda of the press in any topic under evaluation. Gauseth (2012) opines that salience can also be achieved by including viewpoints from one side of an armed conflict while excluding other actors. This means that including or excluding certain sources when reporting about a news story can have an influence on news presentation and perception of the issue under investigation and aligns the press towards a particular agenda. Berkowitz (2009) pertinently asks how journalists' use of news sources leads towards a specific news agenda that either favors or excludes some issues over others.

This exclusion or inclusion will have an effect on how the public or other actors in the issues interpret reported news stories. If the news sources for a story are particularly from one faction of events, the story is expected to be written in favour of the faction that provides the news sources. Boko Haram has often times attacked journalists attributing it to the role of journalists in presenting government side of the story and neglecting their own account of events (Reporters Without Border, 2013; Abang, 2017).

Scholars have documented the relevance of news sources and how they influence news stories and also how the choice of sources enables framing when writing reports (Manning, 2001; Schneider, 2011). From evidence, Schneider (2011) advocated that the use of sources and quotes allows reporters to beckon the voices of their various sources to construct stories in particular ways to suit the narrative they are projecting based on their personal bias or house style. van Dijk (1988) 
contends that "quotations allow the insertion of subjective interpretation, explanations, or opinions about current news events, without breaking the ideological rule that require(s) the separation of facts from opinions" (152). Therefore, it is of paramount importance that journalists stick to objectivity when writing news articles. Stories should go beyond personal idiosyncrasies of the journalists, but include an objective outlook where as much facts are laid bare to allow the audience make informed decisions on how best to react to the subject under consideration.

In being objective when citing sources, gender has to be taking into consideration, as the effects of conflicts are felt both by men and women even though in most crises situations, the men are the principal actors, but the role of women are equally important and not to be downgraded or ignored. In considering the Boko Haram crises for instance, women are the most affected and as such, should be given the opportunity to present their side of the story. They are the ones mainly kidnapped, raped, used as mules to carryout suicide missions and adding the religious dimension, are forcibly married off to Boko Haram fighters as conquests. The psychological traumas they undergo make some of them reluctant to leave their Boko Haram husbands even when rescued, some choose to return back to the terrorist camps (Gaffey, 2017; Matfess, 2017; Sieff, 2016; Odeyemi, 2015; Ibeh \& Audu, 2014). Gender imbalance has however been well documented in journalism among reporters as several studies have found out that men dominate the bylines of most news reports (Ponsford, 2017; Women Media Center, 2017; Shapiro, 2012; Yaegar, 2012; Djerf-Pierre, 2007). If this is the case, it is possible the men may prefer using other men as sources in news reports while ignoring female sources even in cases where they are all involved and affected.

Another key point in the reporter-source dynamics is that, if the journalistic paradigm calls for referring to authoritative news sources for information, then those presumed to hold authority will be at an advantage in getting their views reported as news. Such official sources also tend to symbolize the legitimacy of the societal power structure (Sigal, 1973; Soloski, 1989; Manning, 2001; Berkowitz, 2009). This happens according to Berkowitz (2009) because the job of journalists is to produce news content that bears the aura of factuality: the statements of credible sources can be taken as fact, certifying the news without the need to research the veracity of that "fact" because of the official position the source holds in the society and the authority that comes with that position.

When trying to understand whether the newspaper reports in Nigeria frame the military positively or negatively, we can have an indication from the cited sources of stories about military operations against the terrorist group. Stories that contain mainly military sources are expected to be written favourably for the military while those not containing military sources may be expected to contain stories not very flattering to the military. If the sources are mainly from the Boko Haram group, the report will be negative against the military. To get some measure of objectivity, stories should contain official military sources giving information about government operations, which should be corroborated by other sources on ground such as civilian residents, civil society organisations, stakeholders or other observatory groups with links to other sources for a measure of accuracy, truth, objectivity and factuality.

Quintessentially, the dynamic that exists between journalists and their sources has been portrayed by scholars as a struggle for power over public opinion and public consent (Blumler \& Gurevitch, 1981; McQuail, 2010; Anderson, Peterson, \& David, 2005; Berkowitz, 2009). Berkowitz (2009) is of the view that ethics of the profession does not allow reporters to have an opinion when reporting on an event, however, their opinion could be limited to things such as describing settings, crowd size, appearance of people and what they said. Ericson (1999) earlier theorized that by following this source-driven process, journalists become society's scientists and the news they produce becomes their scientific report because they can be empirically verified to qualify as truth. However, reporting terrorism has become more difficult with prevalent cases occurring nearly in every part of the developed and developing nations.

News agencies are also sources for news reports. Journalists find them credible and most times cite them verbatim or near verbatim in news articles (Johnston \& Forde, 2011)). Pearson and Brand (2001) found that most journalists believed news agencies services more than other media. Pearson and Brand found that $78 \%$ of journalists and news producers used news agencies as news sources most days-and that it was considered a credible source, comparable to metropolitan newspapers. Johnston and Forde (2011) opine that a similar result was obtained in an earlier study by Raward and Johnston (2009). In our opinion, their credibility also depends on their owners, agencies run as a business unit such as Reuters, Agency French Press (AFP), etc. will be more credible compared to agencies that are state controlled like Xinhua (China), ITAR TASS (Russia).

The reports from state controlled agencies will tend to support the government position. Press agencies have been active in reporting the Boko Haram crises as the Boko Haram group has been known to release press material through AFP. The major news agency in Nigeria is state controlled News Agency of Nigeria (NAN), they have also been quoted as sources in many reports especially about military operations against Boko Haram group in Nigeria. Our study will attempt to document instances where press agencies are used as sources for military news reports.

\section{Conclusion}

In the words of Alli (2001), press because of their functions are bound to have conflicts with state security organisations especially when they are perceived as threats to the state and those running the state are quick to exploit this situation. He quotes Brigadier Magashi, a member of the late General Abacha's inner circle as saying in relation to the press, "you are either with us or an enemy, and enemies are meant to be dealt with decisively before they can cause harm". This is a typical Nigerian military mindset where to them, the society is divided into two categories; friends and enemies, and the enemies are to be put 
in their place decisively no matter who they are. These assertions should not concern the press, but rather points of view that promote integrity and independence of the press while espousing accuracy and the truth to promote the ethos of journalism.

\section{References}

i. 360News (2016). Nigerian army reacts to viral video of soldiers begging Buhari for food, water. Retrieved from https:/ / www.360nobs.com/ 2016/ 12/ nigerian-army-reacts-viral-video-soldiers-begging-buhari-food-water/

ii. Abang, M. (2017). A tale of resilience: Journalists working under the veil of Boko Haram. Sahara Reporters. Retrieved from www.saharareporters.com/ 2017/ 01/ 14/ tale-resilience-journalists-working-under-veil-boko-haram

iii. Adeyemi, A. (1998). The Nigerian press under the military. In Lyn S. Graybill, Kenneth W.

iv. Thompson (Eds.), Africa's second wave of freedom: development, democracy, and rights. Lanham, Maryland: University Press of America.

v. Akinkuotu, E., Umukoro, A., Akinloye, B., \& Aluko, O. (2017, May 21). FG paid 2m for Chibok girls release - Report. The Punch. Retrieved from www.punchng.com/ fg-paid-e2m-for-

vi. Alli, C. (2001). The Federal Republic of Nigerian Army: The siege of a nation. Lagos: Malthouse Press Limited.

vii. Aluko, O. (2017, November 6). Anonymous soldier writes Buhari, alleges gross corruption. The Punch. Retrieved from http:/ / punchng.com/ anonymous-soldier-writes-buhari-alleges-gross-corruption/

viii. Amnesty International (2018). Nigeria: Starving women raped by soldiers and militia who claim to be rescuing them. Retrieved from https:/ www.amnesty.org/ en/ latest/ news / 2018/05 / nigeria-starving-women-raped-by-soldiersand-militia-who-claim-to-be-rescuing-them/

ix. Anderson, A., Peterson, A., \& David, M. (2005). Communication or spin? Source-media relations in science journalism. In S. Allan (Ed.), Journalism: Critical issues (pp. 188-198). Berkshire \& New York: Open University.

x. Audu, O. (2014, April 17). Borno government officials, Principal say military lied about rescue of abducted school girls. Premium Times. Retrieved from http://www.premiumtimesng.com/news/ 15 8911- borno- government-officialsprincipal-say-military-lied-rescue-abducted-school-girls.html

xi. Audu, O. (2013, May 17). Nigerian military shut GSM telecommunications in Maiduguri in hunt for Boko Haram. Premium Times. Retrieved from http:// www.premiumtimesng. com/news/ 13476-nigerian-military-shut-gsmtelecommunications-in-maiduguri-in-hunt-for-boko-haram.html

xii. Ayoola, K. A. \& Olaosun, I. E. (2014). Media Representation of Boko Haram in Some Nigerian Newspapers", International Journal of English Linguistics, 4(3), 49---58

xiii. Baker, A. (2015, February 10). Nigeria's military quails when faced with Boko Haram. Time. Retrieved from http:/ / time.com/ 37002849/ nigerias-army-boko-haram

xiv. Blumler, J., \& Gurevitch, M. (1981). Politicians and the press: An essay on role relationships. In D. Nimmo \& K. Sanders (Eds.), Handbook of political communication (pp. 467-493). Newbury Park, CA: Sage.

xv. Berkowitz, D. A. (2009). Reporters and their sources. In K. Wahl-Jorgensen \& T. Hanitzsch (Eds.), The handbook of journalism studies (pp. 102-115). New York, NY: Routledge

xvi. Bervanakis, M. (2017, March 23). London attacks: A timeline of recent terror incidents in the city. News Corp Australia Network. Retrieved from http:// www.news.com.au/ world/ europe/ london-attacks-a-timeline-of-recent-terrorincidents-in-the-city/ news-story/ f2232364217644b69002c5c5fd88120c

xvii. Carroll, C. \& McCombs, M. (2003). Agenda setting effects of business news on the public's images and opinions about major corporations'. Corporate Reputation Review, 6, 36-46.

xviii. Carvell, M. (2014). RE; Boko Haram video apparently shows beheading of Nigeria pilot [Video file]. Retrieved from https:/ / m.youtube.com/ watch?v=MkFdcIMC-rY

xix. CNN (2013, March 3). Boko Haram releases beheading video [Video file]. Retrieved from https:/ / m.youtube.com/ watch?v=t3Kftp5mNlw

xx. Dan Fulani, I. (2014, May 5). How corrupt army commanders undermine fight against Boko Haram. Retrieved from htpps:/ / www.icirnigeria.org/ how-corrupt-army-commanders-undermine-fight-against-boko-haram/

xxi. Dauda, Y. (2018). Rape of IDP women: Amnesty International's report against Nigerian Army lacks credibility, says presidency. Retrieved from http:// www.criticaltimesnews.com /2018/05/ rape-of-idp-women-amnestyinternational-report-army-lacks-credibility-shehu.html?m=1

xxii. Defence Headquarters (2018). Intended malicious report by Amnesty International on the Nigerian Armed Forces. Retrieved from http:// defenceinfo.mil.ng/intended-malicious-report-by-amnesty-international-on-the-nigerianarmed-forces/

xxiii. Djerf-Pierre, M. (2007). The gender of journalism: The structure and logic of the field in the twentieth century. Nordicom Review, Jubilee Issue, 81-104.

xxiv. Ekwueme, A. C. \& Obayi, P. M. (2012). Boko Haram assault on Nigeria: Towards effective mass media response. New Media and Mass Communication. 5, 1-7.

xxv. Ericson, R. (1999). How journalists visualize fact. The Annals of the American Academy of Political and Social Science, 560(1), 83-95. 
xxvi. Erunke, J. (2017, March 16). Boko Haram: Why troops were refusing to go to battle front - DHQ. Vanguard. Retrieved from http:/ / www.vanguardngr.com/ 2017/ 03/ boko-haram-troops-refusing-go-battle-front-dhq/

xxvii. Foster, A. (2017, May 24). Terror attacks timeline: From Paris and Brussels terror to most recent attacks in Europe. Daily Express. Retrieved from http:/ / www.express.co.uk/ news/ world/693421/ Terror-attacks-timeline-FranceBrussels-Europe-ISIS-killings-Germany-dates- terrorism

xxviii. Freyenberger, D. (2013). Amanda Knox: A content analysis of media framing in newspapers around the world. Electronic Theses and Dissertations. Paper 1117. Retrieved from http:/ / dc.etsu.edu/ etd/ 1117

xxix. Gaffey, C. (2017). ISIS just started using female suicide bombers, but Boko Haram has been doing it for years-and shows no sign of stopping. Newsweek. Retrieved from http:/ / www.newsweek.com/ isis-boko-haram-nigeria-suicidebomber-649790

xxx. Gauseth, D. (2012). Framing the Russia-Georgian War: An analysis of the Norwegian print-press coverage in August 2008. Master's thesis submitted to the department of History and Classical Studies, Norwegian University of Science and Technology, Trondheim, Norway.

xxxi. Global Terrorism Index (2016). Measuring the impact of terrorism. Sydney, New York: The Institute for Economics and Peace.

xxxii. Hamid, A. M. \& Baba, I.M. (2014). Resolving Nigeria's 'Boko Haram' insurgence: What role for the media? Social and Behavioral Sciences, 155, $14-20$.

xxxiii. Haruna, A. (2017). Boko Haram: Nigerian troops owed two months allowances cry out. Premium Times. Retrieved from https:/ / www.premiumtimesng.com/ regional/ nnorth-east/ 246020-boko-haram-nigerian-troops-owed-twomonths-allowances-cry.html/amp

xxxiv. Heine, H. (2006). Ludwig Borne - a memorial. Woodbridge: Boydell \& Brewer, Camden House.

xxxv. Hoffman, B. (2006). Inside terrorism. New York: Columbia University Press.

xxxvi. Humayun, S. I. \& Ramani, R. (2015). Military-Media relations in India and Pakistan: A comparative study. Area Studies, 9(1), 76-101.

xxxvii. Ibeh, N. (2014, April 17). Nigerian military retracts claim it freed 107 abducted schoolgirls, says students are still missing. Premium Times. Retrieved from http:// www.premiumtimesng.com/news/ 158970-nigerian-militaryretracts-claim-freed-107-abducted-schoolgirls-says-students-still-missing.html

xxxviii. Ibeh, N. \& Audu, O. (2014, April 16). Nigerian military says it frees 107 kidnapped female students, 8 still missing. Premium Times. Retrieved from http:// www.premiumtimesng.com/ news/ 158901-breaking-nigerian-military-saysit-frees-107-kidnapped-female-students-8-still missing.html

xxxix. Ibekwe, N. (2017, January 24).Nigerian Army Vows To Charge PREMIUM TIMES For 'Fraudulently Obtaining' Military Information. Sahara Reporters. Retrieved from http://saharareporters.com/2017/01/24/ nigerian-army-vowscharge-premium-times-\%E2\%80\%98fraudulently-obtaining\%E2\%80\%99-military-information

xl. Ibekwe, N. (2015, June 7). Cancel Tompolo's multi-billion Naira security contract, group tells Buhari. Premium Times. Retrieved from http://www.premiumtimesng.com/news/ head lines/184487-cancel-tompolos-multi-billion-nairasecurity-contract-group-tells-buhari.html

xli. Idowu, K. (2017, July 27). Ambush of oil workers: Corpses of 18 soldiers, 30 others arrive Maiduguri. The Punch. Retrieved from http:/ / punchng.com/ ambush-of-oil-workers-corpses-of-18-soldiers-30-others-arrive-maiduguri/

xlii. Johnston, J. \& Forde, S. (2011). The silent partner: News agencies and 21st century news. International Journal Of Communication, 5, 195-214.

xliii. Jönsson, A. (2011). Framing environmental risks in the Baltic Sea: A news media analysis. Ambio, 40 (2), 121-132.

xliv. Lawrence, O.D. (2011). Nigerian media coverage of the Boko-Haram crisis. Journal of Journalism and Crises Studies. 12(10). 90-100.

xlv. Lippmann, Walter (1922). Public opinion. New York: Macmillan.

xlvi. Manning, P. (2001). News and news sources: A critical introduction. London: Sage.

xlvii. Matfess, H. (2017). Rescued and deradicalised women are returning to Boko Haram. Why? Retrieved from http:/ / africanarguments.org/ 2017/ 11/ 01/ rescued-and-deradicalised-women-are-returning-to-boko-haram-why/

xlviii. McCombs, M. (2005). A look at agenda-setting: Past, present and future. Journalism Studies, 6(4), 543-557.

xlix. McCombs, M.E., \& Reynolds, A. (2002). News influence on our pictures in the World. In Media effects: Advances in theory and research, 2nd ed., eds. J. Bryant and D. Zillman, 1-18, Hillside, NJ: Erlbaum.

1. McCombs, M.E., D.L. Shaw, \& D. Weaver, (eds.) (1997). Communication and democracy: Exploring the intellectual frontiers in agenda-setting theory. New York: Routledge.

li. McCombs, M.E., \& D.L. Shaw. (1972). The agenda-setting function of mass media. Public Opinion Quarterly, 36(2): 17687.

lii. McCombs, M. (1997). New Frontiers in Agenda Setting: Agendas of Attributes and Frames. paper presented at the annual meeting of Association for Education in Journalism and Mass Communication, Chicago, USA.

liii. McKinnon, A.M. (2005). Reading opium of the people: Expression, protest and the dialectics of religion. Critical Sociology, 31(1-2), 15-38.

liv. Mcquail, D. (2010) Mass Communication Theory (6 $6^{\text {th }}$ ed.). London: Sage Publications. 
lv. Ngige C. V., Badekale, A. F. \& HammanJoda I., (2016). The media and Boko Haram insurgency in Nigeria: A content analysis and review. International Journal of Peace and Conflict Studies, 3(1), 58-65.

lvi. Nnanna, O. (2016, December 29). The capture of Sambisa Forest. Vanguard. Retrieved from https:/ / www.vanguardngr.com/ 2016/ 12/ capture-sambisa-forest/

lvii. Nwabughiogu, L. (2016, May 18). Corruption in military responsible for Nigeria's loss of 14 LGAs to Boko Haram Buhari. Vanguard. Retrieved from https:// www.vanguardngr. com/2016/ 05/ corruption-military-responsiblenigerias-loss-14-lgas-boko-haram-buhari/

lviii. Nwokegi, S. N. (2009). The effect of media laws on Nigerian print media: A study of three newspapers in Port Harcourt, Rivers State. Unpublished Master's thesis, University of Nigeria, Nsukka.

lix. Nzimiro, I. (1988). The Government and press: What relationship In Ralph Akinfeleye (ed.). Contemporary issues in mass media for development and national security. Lagos: U I Media Publications Ltd.

lx. O'Brien, W. A. (1995). Novalis, signs of revolution. Duke: Duke University Press.

lxi. Odeyemi, J. (2015, Dec 7). Military advances deep into Sambisa Forest. Daily Trust. Retrieved from https:/ / www.dailytrust.com.ng/ news/ general/ military-advances-deep-into-sambisa-forest/ 123048.html

lxii. Ogundipe, S. (2017, January 19). Nigerian Police detain Premium Times publisher, journalist on 'orders from above'. Premium Times. Retrieved from http:/ / www.premiumtimesng.com/ news/ headlines/ 221029-nigerian-police-detainpremium-times-publisher-journalist-orders.html

lxiii. Ogundipe, S. (2016, October 14). Untold story of the deal that yielded the rescue of 21 Chibok girls. Premium Times. Retrieved from http://www.premiumtimesng.com/news/headlines/ 212732-untold-story-deal-yielded-rescue-21chibok-girls.html

lxiv. Okoye, I. (2003). Historical overview and analysis of government-media relationship in Nigeria from 1900 - 2001 In R. A. Akinfeleye \& I. Okoye (2003). Issues in Nigerian media history: 1900-2000 AD. Lagos: Malthouse Press Limited

lxv. Olagunju, F.B. \& Ajadi, R.A. (2014). The Media and the Ideology of Insecurity: A Critical Discourse Analysis of Two Editorials on Federal Government-Boko Haram Face-off. Review of Journalism and Mass Communication, 2(1), 33-46

lxvi. Olayinka, A. P. \& Onwuka, V. I. (2016). The perception of Lagosians on media coverage of Boko Haram insurgency. International Journal of Information and Knowledge Management, 2, 8-21.

lxvii. Osas, P. (2014). Incredible: Mutiny in the Nigerian army camp in Maiduguri; soldiers fire at Gen. Mohammed's convoy. Retrieved from http:// www.thescoopng.com/2014/05/14/ incredible-mutiny-nigerian-army-camp-maidugurisoldiers-fire-gen-mohammeds-convoy/

lxviii. Osu, L., \& Pate, U. (eds.) (2011). Mass media and society in Nigeria (2nd Edition). Lagos: Malthouse Press.

lxix. Pavelka, J. (2014). The factors affecting the presentation of events and the media coverage of topics in the mass media. Procedia - Social and Behavioral Sciences, 140, 623 - 629

lxx. Pearson, M., \& Brand, J. (2001). Sources of news and current affairs. epublications@Bond, Bond University. Retrieved from http:/ / epublications.bond.edu.au/ hss pubs/ 96

lxxi. Peresin, A. (2007). Mass Media and Terrorism. Medij. Istraž, 13(1), 5-22.

lxxii. Phipps, C. \& Weaver, M. (2016). What we know so far about the Berlin Christmas market attack. The Guardian. Retrieved from https:/ / www.theguardian.com/ world/ 2016/ dec/ 20/ berlin-terrorist-attack-what-we-know-so-far

lxxiii. Ponsford, D. (2017). Study finds little change in five years as male bylines dominate UK national newspaper front pages. Retrieved from http:// www.pressgazette.co.uk/study-finds-little- change-in-five-years-as-male-bylinesdominate-uk-national-newspaper-front-pages/

lxxiv. Popoola, I. S. (2012). Press and terrorism in Nigeria: A discourse on Boko Haram. Global Media Journal African Edition, 6 (1), 43-66.

lxxv. Potter, W.J. (2008). Arguing for a general framew ork for mass media scholarship. Thousand Oaks, CA: Sage.

lxxvi. Premium Times (2018, May 24). How Nigerian soldiers, JTF rape, starve Boko Haram victims - Amnesty International. Premium Times. Retrieved from https://www.premiumtimesng. com/news/headlines/269548-how-nigeriansoldiers-jtf-rape-starve-boko-haram-victims.html

lxxvii. Rather, D. (2012, September 11). Media's balancing act with terrorism. CNN. Retrieved from http:/ / www.cnn.com/ 2012/ 09/ 11/ opinion/ rather-media-and-terrorism/ index.html

lxxviii. Raward, D., \& Johnston, J. (2009). FM radio news: Spreading the news or spread too thin? Australian Journalism Review, 31(1), 63-76.

lxxix. Reporters Without Border (2013). Predators of the Press Freedom 2013. Paris: Reporters Without Borders.

lxxx. Schneider, B. (2011). Sourcing homelessness: How journalists use sources to frame homelessness. Journalism, 13(1), $71-86$.

lxxxi. Seng, M. P., \& Hunt, G. T. (1986). The Press and Politics in Nigeria: A Case Study of Developmental Journalism, Boston College Third World Law Journal, 6(2), Retrieved from http:/ lawdigitalcommons.bc.edu/ twlj/ vol6/ iss2/ 1

lxxxii. Shapiro, R. (2012). Men Still Dominating Bylines In Journalism: Report. Retrieved from https:/ / www.huffingtonpost.co.za/ entry/ byline-survey-men-women-journalism_n_1552210 
lxxxiii. Shehu, A. (2015). Press coverage of the Boko Haram insurgency and its implications for conflict-sensitive journalism in Nigeria (2013/2014). Dissertation submitted to the School Of Post Graduate Studies, Ahmadu Bello University, Zaria, Nigeria.

lxxxiv. Shettima, K. (2015, July 26). Democracy and Security in Northeast: The Borno Story. Daily Trust. Retrieved from https:/ / www.dailytrust.com.ng/ sunday/ index.php/ politics/ 21436-democracy-and-security-in-northeast-the-bornostory-gov-shettima

lxxxv. Sieff, K. (2016, April 3). They were freed from Boko Haram's rape camps. But their nightmare isn't over. Washington Post. Retrieved from https:/ / www.washingtonpost.com/ world/africa/ they-were-freed-from-boko-harams-rapecamps-but-their-nightmare-isnt-over/ 2016/ 04/ 03/ dbf2aab0-e54f-11e5-a9ce$681055 \mathrm{c} 7 \mathrm{a} 05 \mathrm{f}$ story.html?utm term $=.5954 \mathrm{fdfb} 0 \mathrm{efe} \&$ noredirect $=0 \mathrm{n}$

lxxxvi. Sigal, L. (1973). Reporters and officials. Lexington, MA: D.C. Heath.

lxxxvii. Singh, A. K. (2006). Military and media. Lancer Publishers \& Distributors: New Delhi.

lxxxviii. Soloski, J. (1989). News reporting and professionalism. Media, Culture \& Society, 11, 207-228.

lxxxix. The Punch (2016, December 21). Soldiers fighting Boko Haram beg Buhari for food, water. Retrieved from http:/ / punchng.com/ video-soldiers-fighting-boko-haram-beg-buhari-food-water

xc. The Young Turks (2015). New Boko Haram tape released: Two beheaded in Nigeria. [Video file] https:/ / m.youtube.com/ watch?v=yZTFc6Y 9dY

xci. Udomisor, I. W., \& Anayo, O. S. (2013). a critique of the performance of the Nigerian press in the current democratic dispensation. International Journal of Management Sciences, 1(8), 272-281

xcii. Ujah, E. (2012, March 20). Why we awarded waterways contract to Tompolo - FG. Vanguard. Retrieved from https:/ / www.vanguardngr.com/ 2012/ 03/ why-we-awarded-waterways-contract-to-tompolo-fg/

xciii. Ukpong, C. (2017b, May 7). Buhari confirms Nigerian govt swapped 82 Chibok girls for Boko Haram "suspects". Premium Times. Retrieved from http:// www.premiumtimesng.com/ news/top-news/230529-buhari-confirmsnigerian-govt-swapped-82-chibok-girls-for-boko-haram-suspects.htmlvan Dijk, T. A. (1988). News as discourse. New Jersey: Lawrence Erlbaum Associates.

xciv. Vourlias, C. (2015, April 7). Fears linger around Nigerian president's commitment to a free press. Aljazeera News. Retrieved from http:/ / america.aljazeera.com/ articles/ 2015/ 4/ 7/ fears-linger-about-nigerian-presidentscommitment-to-press-freedom.html Walsh, J.I. (2010). Media attention to terrorist attacks: Causes and consequences. Institute for Homeland Security Solutions, Research Brief, 1-15.

xcv. Women Media Center (2017). Women's Media Center Report: Women journalists report less news than men; TV gender gap most stark. Retrieved from http:/ / www.womensmedia center.com/ about/ press/ press-releases/ womensmedia-center-report-women-journalists-report-less-news-than-men-tv-g

xcvi. Yaeger, T. (2012). The byline survey report, 2012: Who narrates the world? Retrieved from https:/ / theopedproject.wordpress.com/ 2012/ 05/ 28/ the-byline-survey-2011/ 